\title{
A prospective comparative study to evaluate the efficacy and safety of olopatadine eye drops and bepotastine eye drops in subjects of vernal kerato conjunctivitis
}

\author{
Amatur R. Malahat, Sudhakar Kodudula*, Vijaya L. Gali
}

Department of Pharmacology, Bhaskar Medical College, Moinabad, Telangana, India

Received: 16 March 2020

Revised: 18 April 2020

Accepted: 20 April 2020

*Correspondence:

Dr. Sudhakar Kodudula,

Email: drsudhakar19@gmail.com

Copyright: (C) the author(s), publisher and licensee Medip Academy. This is an open-access article distributed under the terms of the Creative Commons Attribution Non-Commercial License, which permits unrestricted non-commercial use, distribution, and reproduction in any medium, provided the original work is properly cited.

\begin{abstract}
Background: Vernal keratoconjunctivitis (VKC) is an allergic eye disease that especially affects young boys. Both olopatadine and bepotestine are dual acting drugs that provide rapid symptomatic relief coupled with the long-term disease-modifying benefit. The present study is conducted to compare the efficacy and safety of olopatadine eye drops and bepotastine eye drops in patients of vernal keratoconjunctivitis.

Methods: A prospective, randomized, parallel-group, comparative study is conducted over a period of 4 weeks on paediatric patients with VKC. 50 patients are recruited and randomized into two treatment groups. They received the assigned drugs for 4 weeks and are called for follow up at the end of 1st week, 4th week and 12th week. At each follow-up, patients are examined and the clinical parameters are graded.

Results: This study shows that both olopatadine and bepotastine are equally efficacious. Bepotastine provided quicker relief to symptoms of watering, ocular discomfort and conjunctival hyperaemia. Number of responders are also more in the bepotastine group. Absolute eosinophilic count improved with both the drugs but there is no statistically significant difference between them. Both drugs showed good safety profile. However, $24 \%$ patients reported aversion to bitter taste with bepotastine. There is no treatment related severe adverse effects in both the groups.

Conclusions: Both olopatadine and bepotastine are effective in treating vernal keratoconjunctivitis. However, bepotastine performed better in reducing tearing, ocular discomfort and conjunctival hyperaemia.
\end{abstract}

Keywords: Bepotastine, Efficacy, Olopatadine, Safety, Vernal keratoconjunctivitis

\section{INTRODUCTION}

Allergy is the fifth leading chronic disease in the world. It affects about $40 \%$ percentage of the entire population. ${ }^{1}$ The prevalence of allergic diseases among children between 6-14 years is gradually increasing and varies from $0.3 \%$ to $20.5 \% .^{2}$ A single cause for allergic disease cannot be pointed out and we should consider a contribution of many factors like genetics, early childhood exposure, air pollution, pets and other factors. ${ }^{2}$
Ocular allergy represents one of the most common conditions encountered by ophthalmologists. Allergic conjunctivitis (AC) both acute or chronic, is associated with allergic rhinitis (AR) in 30\%-70\% of affected individuals. $^{3}$ The term allergic conjunctivitis includes Seasonal allergic conjunctivitis (SAC), perennial allergic conjunctivitis (PAC), vernal keratoconjunctivitis (VKC), and atopic keratoconjunctivitis (AKC). Seasonal allergic conjunctivitis (SAC) and perennial allergic conjunctivitis (PAC) are the most common forms of ocular allergies 
which are estimated to affect at least $15-20 \%$ of the population. ${ }^{4}$

Vernal catarrh or vernal keratoconjunctivitis (VKC) comprises $0.5 \%$ of allergic eye disease. VKC can induce irreversible corneal changes that profoundly impair vision. VKC most commonly occurs in boys living in warm, dry, subtropical climates, such as India. ${ }^{5} \mathrm{VKC}$ is a chronic, bilateral, at times asymmetrical, seasonally exacerbated, allergic inflammation of the ocular surface, involving tarsal and/or bulbar conjunctiva. It is an IgEand $\mathrm{T}$ cell-mediated disease, leading to a chronic inflammation, in which eosinophil, lymphocyte and structural cell activation characterize the conjunctival allergic reaction. ${ }^{6}$

Drugs like alcaftadine, azelastine, bepotastine, epinastine, ketotifen, and olopatadine, have dual mode of action. ${ }^{7}$ The advantage offered by these agents is the rapidity of symptomatic relief given by immediate histamine receptor antagonism which alleviates itching and redness, coupled with the long-term disease-modifying benefit of mast cell stabilization. ${ }^{8}$

Since VKC is a disease of the younger age group and it effects the day to day functioning of the patient, morbidity due to this condition causes loss of school time. This, in the long run, negatively impacts learning and overall development of these young individuals. Being a chronic condition, judicious use of medication is needed for a prolonged period. School attendance, performance, lifestyle, and social activities are affected.

Olopatadine with a wide action spectrum has shown to be very effective in VKC. ${ }^{9}$ Bepotastine though a relatively newer and less commonly used drug has also shown promising results. ${ }^{10}$ In India very few studies are done in vernal keratoconjunctivitis comparing $0.1 \%$ olopatadine and bepotestine $1.5 \%$ eyedrops. Hence this study is being taken up to see their suitability in Indian population.

\section{METHODS}

This is an open labelled, single centre prospective randomised study conducted on 50 patients of $\mathrm{VKC}$ attending ophthalmology outpatient department of Bhaskar General Hospital.

Study population includes patients attending ophthalmology outpatient department of Bhaskar General Hospital satisfying the eligibility criteria.

Study was conducted in Bhaskar Medical College and General Hospital (Department of Pharmacology, in collaboration with Department of Ophthalmology Bhaskar Medical College)

Duration of study was of 3months after the first visit for each subject. Study period was from January 2017 to June 2018.
Sample size involves group a-olopatadine-25 patients. group b-bepotastine-25 patients (total 50 patients).

\section{Inclusion criteria}

All newly diagnosed patients of VKC attending Dept of Ophthalmology Bhaskar General Hospital whose parents/guardians are willing to give informed consent, aged 5 years or more, those willing to come for follow ups, as advised were included.

\section{Exclusion criteria}

Age less than $5 \mathrm{yrs}$, patients on previous treatment for VKC for the past month, before their first visit, contact lens wearers during the period of study, subject having active ocular infections, serious ocular pathological conditions, patients with ocular surface disorders like pterygium, dry eyes blepharitis and ocular co morbidities like uveitis or glaucoma, history of ocular surgery within 3 months, patients with severe VKC requiring steroids, cyclosporine, tacrolimus or other immunosuppressant drugs, immunocompromised patients, pregnant and lactating women, patients who have known hypersensitivity to the study drugs including benzalkonium chloride which is used as preservative in ophthalmic solution

The study is conducted after obtaining the approval from institutional ethics committee. All the study patients are less than 18 years of age. So, their parents/ guardians are explained about the study purpose, procedures involved and a written informed consent is obtained from them.

After screening 73 patients, 50 patients satisfying the inclusion and exclusion criteria are enrolled in the study during 1st visit. Once the subject is enrolled into the study, height, weight and visual acuity measurements are done. The enrolled patients are randomized by simple randomization (odd/even number method) into group $\mathrm{A}$ or group B

\section{Treatment plan}

Group A patients received olopatadine hydrochloride $0.1 \%$ ophthalmic solution 1 drop on affected eye TID for 12 weeks. Group B patients were treated with bepotastine besilate $1.5 \%$ ophthalmic solution1drop on affected eye BD for 12 weeks.

The assessment of patients is done by history taking, clinical and slit lamp examination by an ophthalmologist. The ocular symptoms like itching, discomfort, watering, and foreign body sensation are assessed by interviewing the patients and graded according to severity (grade 0absent, grade1-mild, grade 2-moderate, grade 3-severe). The ocular signs such as conjunctival hyperaemia and papillary hypertrophy are assessed. The signs are also graded depending upon the severity into (grade 0-absent, grade1-mild, grade 2-moderate, grade 3-severe). 
Parents are instructed to come for 3 more visits after baseline visit; visit-1 or baseline visit, visit-2 or 1 st follow up (FU-1) at the end of 1 week, visit-3 or 2nd follow up (FU-2) at the end of 4 weeks, visit-4 or 3rd follow up (FU-3) at the end of 12 weeks. Various steps taken and procedures done at each visit are shown in the table (Table 1).

Table 1: Various steps taken and examinations done at each visit.

\begin{tabular}{|c|c|c|c|c|}
\hline Activity & $\begin{array}{l}\text { Visit- } \\
1\end{array}$ & FU-1 & FU-2 & $\begin{array}{l}\text { FU- } \\
3\end{array}$ \\
\hline $\begin{array}{l}\text { Screening and } \\
\text { enrolment }\end{array}$ & $\checkmark$ & - & - & - \\
\hline $\begin{array}{l}\text { Informed } \\
\text { consent }\end{array}$ & $\checkmark$ & - & - & - \\
\hline Randomization & $\checkmark$ & - & - & - \\
\hline Medical history & $\checkmark$ & - & - & - \\
\hline $\begin{array}{l}\text { Recording vital } \\
\text { signs }\end{array}$ & $\checkmark$ & $\checkmark$ & $\checkmark$ & $\checkmark$ \\
\hline $\begin{array}{l}\text { General and } \\
\text { systemic } \\
\text { examination }\end{array}$ & $\checkmark$ & $\checkmark$ & $\checkmark$ & $\checkmark$ \\
\hline $\begin{array}{l}\text { Examination of } \\
\text { eyes (including } \\
\text { slit lamp } \\
\text { examination) by } \\
\text { Ophthalmologist }\end{array}$ & $\checkmark$ & $\checkmark$ & $\checkmark$ & $\checkmark$ \\
\hline $\begin{array}{l}\text { Study } \\
\text { Medications } \\
\text { given }\end{array}$ & $\begin{array}{l}1 \\
\text { week }\end{array}$ & $\begin{array}{l}3 \\
\text { weeks }\end{array}$ & $\begin{array}{l}2 \\
\text { months }\end{array}$ & - \\
\hline $\begin{array}{l}\text { Compliance } \\
\text { checked }\end{array}$ & - & $\checkmark$ & $\checkmark$ & $\checkmark$ \\
\hline $\begin{array}{l}\text { Adverse events } \\
\text { recording }\end{array}$ & - & $\checkmark$ & $\checkmark$ & $\checkmark$ \\
\hline $\begin{array}{l}\text { Conjunctival } \\
\text { scraping for } \\
\text { presence of } \\
\text { eosinophils. }\end{array}$ & $\checkmark$ & - & - & $\checkmark$ \\
\hline $\begin{array}{l}\text { Absolute } \\
\text { eosinophil count } \\
\text { (AEC) }\end{array}$ & $\checkmark$ & - & - & $\checkmark$ \\
\hline
\end{tabular}

" $\checkmark$ " Represents activity is done, "--" Represents activity is not done. FU-1: follow up-1, FU-2: follow up-2, FU-3: follow up-3

If any subject develops serious adverse side effects, he/she shall be excluded from the study immediately and the proper remedy will be taken. If any adverse drug reactions are noted, then the causality assessment is done by World Health Organisation Uppsala Monitoring Centre (WHO- UMC) scale. ${ }^{11}$

\section{Statistical analysis}

The demographics, illness and other continuous variables are expressed as mean. Student's T test is applied to test the significance between the two groups. All the above statistical tests are processed by SPSS 16 version.

\section{RESULTS}

All the patients are between 5-15 years of age. $36(72 \%)$ of patients are between 5-10 years of age, while the remaining $14(28 \%)$ patients are between $11-15$ years. Out of the total 50 patients, $39(78 \%)$ are male and the remaining $11(22 \%)$ patients are female.

\section{Socioeconomic status}

Kuppuswamy Socioeconomic status scale is used to assess socioeconomic status of the study patients. ${ }^{12}$ Results are shown in the following table (Table 2).

Table 2: Socio economic status of study participants.

\begin{tabular}{|lll|}
\hline $\begin{array}{l}\text { Socio economic status } \\
\text { Lower middle } \\
\text { socioeconomic status }\end{array}$ & 11 & 22.0 \\
\hline $\begin{array}{l}\text { Lower socioeconomic } \\
\text { status }\end{array}$ & 18 & 36.0 \\
\hline $\begin{array}{l}\text { Middle socioeconomic } \\
\text { status }\end{array}$ & 13 & 26.0 \\
\hline $\begin{array}{l}\text { Upper middle } \\
\text { socioeconomic status }\end{array}$ & 8 & 16.0 \\
\hline Total & 50 & 100.0 \\
\hline
\end{tabular}

\section{Symptom score}

Number of patients having symptoms of itching, excessive tearing, foreign body sensation and ocular discomfort are documented at baseline (visit 1), 1st week (1st follow up), 4th week (2nd follow up) and 12th week (3rd follow up). Mean score and $\mathrm{p}$ value between the two groups are depicted in the (Table 3 ). At the base line, there is no statistically significant difference between the two groups for any symptom. With reference to itching and foreign body sensation, there is no statistically significant difference between the groups at any visit ( $p>0.05)$. However, compared to Olopatadine, Bepotastine provided better reduction of ocular discomfort at FU-2 ( $\mathrm{p}=0.04)$ and FU-3 ( $\mathrm{p}=0.05)$. Bepotastine also performed better in reducing excessive tearing $(\mathrm{p}=0.001$, extremely significant statistical difference) at FU-2.

\section{Signs score}

At the base line, there is no statistically significant difference between the two groups for both the signs. Bepotastine provided better reduction in hyperaemia at FU-2 and FU-3. At FU-2, p value (0.001) is extremely significant whereas at FU-3, p value $(0.003)$ is highly significant. With reference to papillary hypertrophy there is no statistically significant difference between the two groups at any of the visits (Table 4). 
Table 3: Evaluation of subjective symptoms between the two groups.

\begin{tabular}{|lllll|}
\hline \multirow{5}{*}{ Symptoms } & Visit & Group A (mean score) & Group B (mean score) & P value \\
& Baseline & 2.16 & 2.32 & 0.45 \\
\cline { 2 - 5 } & FU-1 & 1.68 & 1.6 & 0.76 \\
\cline { 2 - 5 } Tearing & FU-2 & 1.16 & 1.24 & 0.77 \\
\cline { 2 - 5 } & FU-3 & 0.68 & 0.6 & 0.73 \\
\hline \multirow{5}{*}{ Foreign body } & Baseline & 2.08 & 1.8 & 0.41 \\
\cline { 2 - 5 } sensation & FU-1 & 1.64 & 1.36 & 0.3 \\
\cline { 2 - 5 } & FU-2 & 1.08 & 0.48 & $0.001^{* * *}$ \\
\hline \multirow{5}{*}{ Ocular discomf } & Baseline & 0.32 & 0.12 & 0.57 \\
\cline { 2 - 5 } & FU-1 & 2.04 & 1.84 & 1 \\
\cline { 2 - 5 } & FU-2 & 1.6 & 0.76 & 0.12 \\
\cline { 2 - 5 } & FU-3 & 1.12 & 0.2 & 0.44 \\
\cline { 2 - 5 } & FU-1 & 0.44 & 1.3 & 0.18 \\
\cline { 2 - 5 } & FU-2 & 1.76 & 0.44 & $0.04 *$ \\
\hline
\end{tabular}

Note: $\mathrm{p}$ value by Student's t-test *statistically significant at $\mathrm{p} \leq 0.05, * *$ very significant at $\mathrm{p} \leq 0.01, * * *$ extremely significant at $\mathrm{p} \leq 0.001$.

Table 4: Evaluation of objective signs between the two groups.

\begin{tabular}{|lllll|}
\hline Sign & Visit & Group A (mean score) & Group B (mean score) & P value \\
\hline \multirow{4}{*}{$\begin{array}{l}\text { Conjunctival } \\
\text { hyperaemia }\end{array}$} & Baseline & 2.48 & 2.4 & 0.69 \\
\cline { 2 - 5 } & FU-1 & 1.68 & 1 & $0.001^{* * *}$ \\
\cline { 2 - 5 } & FU-2 & 0.68 & 0.24 & $0.003^{* *}$ \\
\cline { 2 - 5 } $\begin{array}{l}\text { Papillary } \\
\text { hypertrophy }\end{array}$ & Baseline & 1.8 & 0 & - \\
\cline { 2 - 5 } & FU-1 & 1.16 & 1.84 & 0.88 \\
\cline { 2 - 5 } & FU-2 & 0.76 & 0.8 & 0.79 \\
\hline
\end{tabular}

Note: $\mathrm{p}$ value by student's t-test *statistically significant at $\mathrm{p} \leq 0.05$, **very significant at $\mathrm{p} \leq 0.01, * * *$ extremely significant at $\mathrm{p} \leq 0.001$

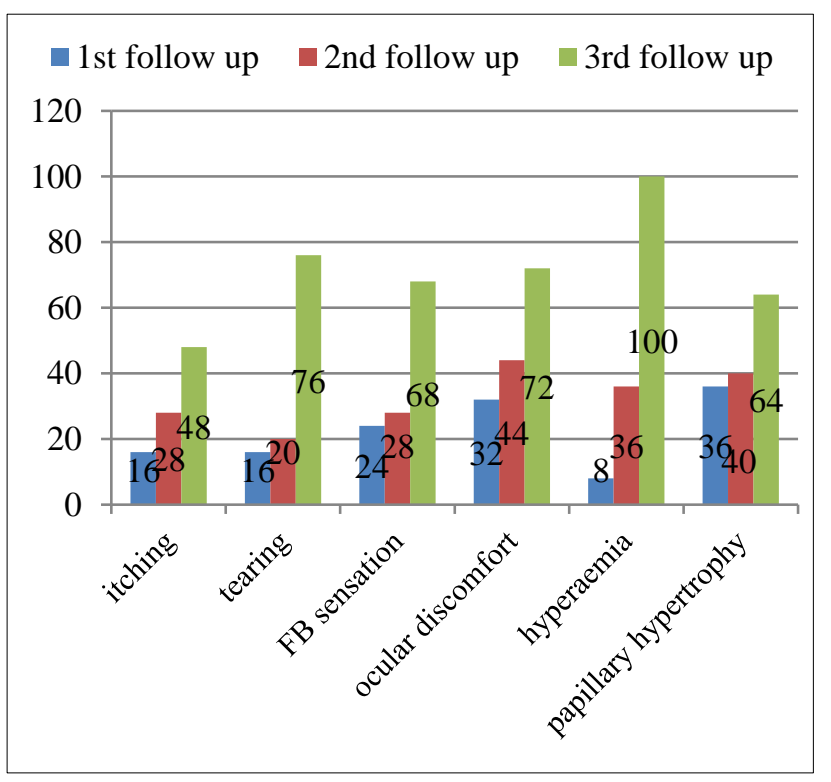

Figure 1: Percentage of responders to various signs and symptoms at each follow up in Group A.
Responders to treatment in each group: The patients getting a symptom grading of 0 in the follow up visits after starting treatment are called Responders. Percntage responders at the end of each follow up visit, for each clinical parameter are compared for Group A and B (Figure 1 and 2).

\section{Laboratory investigations}

In both the groups, histopathology of conjunctival scrapings at the beginning of study showed increased cellularity and presence of eosinophils and mast cells. When the same is repeated at the completion of study (end of 12 weeks), Group A and Group B showed scattered persistence of mast cells in $20 \%$ and $16 \%$ of the patients respectively. The difference between the two groups is not statistically significant. No eosinophils are found in both the groups at the end of study. Both Olopatadine and Bepotastine provided significant reduction in Absolute Eosinophil Count (AEC). Again, the difference between these two groups is not statistically significant (Table 5). 


\section{Adverse events}

In group A, 2 patients had sinusitis and 3 patients had fever. In group B, 5 patients had sinusitis and 4 patients had fever. $24 \%$ of the patients $(6 / 25$ patients) treated with Bepotastine reported mild adverse taste.

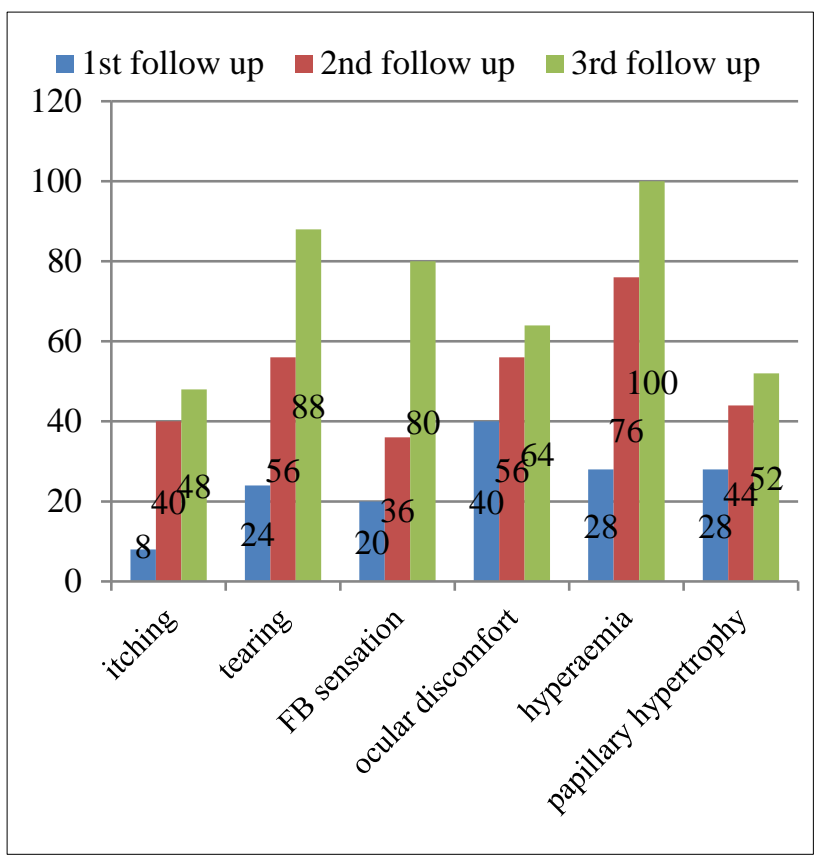

Figure 2: Percentage of responders to various signs and symptoms at each follow up in Group B.

Table 5: Absolute eosinophil count assessment.

\begin{tabular}{|llll|}
\hline AEC & $\begin{array}{l}\text { Group A } \\
\text { (mean } \\
\text { score) }\end{array}$ & $\begin{array}{l}\text { Group B } \\
\text { (mean } \\
\text { score) }\end{array}$ & $\begin{array}{c}\text { P } \\
\text { value }\end{array}$ \\
\hline $\begin{array}{l}\text { Baseline } \\
\left(\mathbf{1}^{\text {st }} \text { visit }\right)\end{array}$ & 452 & 423.8 & 0.15 \\
\hline $\begin{array}{l}\mathbf{3}^{\text {rd }} \text { FU } \\
\left.\mathbf{( 1 2}^{\text {th }} \text { week }\right)\end{array}$ & 163 & 184 & 0.17 \\
\hline
\end{tabular}

Note: $\mathrm{p}$ value by Student's t-test

\section{DISCUSSION}

Understanding the underlying mechanisms implicated in triggering allergy, is important in treating Vernal Keratoconjunctivitis patients. Majority of the patients are in the age range of 5 to 10 years which constitutes $72 \%$ of the total patients (36 patients). This is similar to a study by Leonardi A et al, where, $83 \%$ of patients are under 10 years of age. ${ }^{13}$

The ratio of male to female patients included in this study is $4: 1$ showing a male preponderance for $\mathrm{VKC}$, which is similar to the findings of a study by Saboo et al, wherein a male preponderance for $\mathrm{VKC}$ is observed with male to female ratio of 6.4:1. ${ }^{14}$ Sexual hormones, through their receptors, may influence the activity of eosinophils in patients with VKC. ${ }^{14} \mathrm{We}$ observed the prevalence of lower socio-economic status $(36 \%, 18$ patients) in our study patients which is in contrast to the findings of Stefan de Smedt et al whose study on 3041 children in Rwanda identified higher economic status as a risk factor for VKC. ${ }^{15}$

In this study both drugs are equally effective in treating itching and foreign body sensation. This finding is in contrast with an earlier study by Craig McCabe et al where Bepotastine was superior to Olopatadine in treating ocular itch. ${ }^{16}$ Bepotastine provided better relief to ocular discomfort at 2 nd and 3rd follow ups. Also, Bepotastine showed extremely significant difference in relief from excessive tearing $(\mathrm{p}=0.001)$ at $\mathrm{FU}-2$, compared Olopatadine. This is consistent with the analysis of Craig McCabe et al where $56.7 \%$ of patients chose Bepotastine besilate and $43.3 \%$ (13/30) chose Olopatadine as the preferred agent for tearing relief. ${ }^{16}$

Bepotastine provided better reduction in hyperemia at FU2 and FU-3. At FU-2, With reference to papillary hypertrophy there is no statistically significant difference between the two groups at any of the visits.

Adverse events like fever and rhinitis are noted in few patients ( 3 in Olopatadine and 5 in Bepotastine group). These are non-serious and most probably, are not related to the drugs. $24 \%$ of the patients $(6 / 25$ patients) treated with Bepotastine reported mild adverse taste. This is similar to the study done by McCabe et al where $10 \%$ of the patients reported adverse taste with Bepotastine. ${ }^{15}$ None of the patients discontinued the study.

\section{CONCLUSION}

It may be concluded that both olopatadine and bepotastine are safe and effective in vernal keratoconjunctivitis. Bepotastine performed better in reducing watering, ocular discomfort and conjunctival hyperemia. Bepotastine also has the advantage of twice daily dosing compared to Olopatadine which has to be given thrice daily. Large scale studies involving large number of patients should be conducted to establish the efficacy and safety of these drugs. Bepotastine may be considered as a first line drug for treatment of Vernal Keratoconjunctivitis in India.

\section{ACKNOWLEDGEMENTS}

Authors would like to thank Dr. Ather Mohammed, assistant professor, Department of Ophthalmology, for providing ophthalmic examinations of patients involved in the study. Authors are grateful to Dr. M. Narsing Rao, Principal and Dean, Bhaskar Medical College, Moinabad and Dr. U.S.N Raju Professor and Chief Hospital Administrator for permitting us to carry out the study.

Funding: No funding sources

Conflict of interest: None declared

Ethical approval: The study was approved by the Institutional Ethics Committee 


\section{REFERENCES}

1. Abelson MB, Shetty S, Korchak M, Butrus SI, Smith LM. Advances in pharmacotherapy for allergic conjunctivitis. Expert Opin Pharmacother. 2015;16(8):1219-31.

2. Akil H, Celik F, Ulas F, Kara IS. Dry eye syndrome and allergic conjunctivitis in the pediatric population. Middle East Afr J Ophthalmol. 2015;22(4):467-71.

3. Johansson SG, Bieber T, Dahl R, Friedmann PS, Lanier BQ, Lockey RF, et al. Revised nomenclature for allergy for global use: Report of the Nomenclature Review Committee of the World Allergy Organization, October 2003. J Allergy Clin Immunol. 2004;113(5):832-6.

4. Rosa ML, Lionetti E, Reibaldi M, Russo A, Longo A, Leonardi S, et al. Allergic conjunctivitis: a comprehensive review of the literature. Ital J Pediatr. 2013;39:18.

5. Alemayehu AM, Yibekal BT, Fekadu SA. Prevalence of Vernal Keratoconjunctivitis and its associated factors among children in Gambella town, southwest Ethiopia, June 2018 PLoS One. 2019;14(4): e0215528.

6. Kumar S. Vernal keratoconjunctivitis: a major review. Acta Ophthalmol. 2009;87:133-47.

7. Ackerman S, Smith LM, Gomes PJ. Ocular itch associated with allergic conjunctivitis: latest evidence and clinical management. Ther Adv Chronic Dis. 2016;7(1):52-67.

8. Mishra GP, Tamboli V, Jawla J, Mitra AK. Recent patents and emerging therapeutics in the treatment of allergic conjunctivitis. Recent Pat Inflamm Allergy Drug Discov. 2011;5:26-36.

9. Uchio E. Treatment of allergic conjunctivitis with Olopatadine hydrochloride eye drops. Clin Ophthalmol. 2008;2(3):525-31.
10. Bergmann MT, Williams JI, Gomes PJ. Treatment of allergic conjunctivitis with Bepotastine besilate ophthalmic solution $1.5 \%$. Clin Ophthalmol. 2014;8:1495-505.

11. Zaki SA. Adverse drug reaction and causality assessment scales Lung India. 2011;28(2):152-3.

12. Wani RT. Socioeconomic status scales modified Kuppuswamy and Udai Pareekh's scale updated for 2019. J Family Med Prim Care. 2019;8(6):1846-9.

13. Leonardi A, Bogacka E, Fauquert JL, Kowalski ML, Groblewska A, Jedrzejczak-Czechowicz M, et al. Ocular allergy: recognizing and diagnosing hypersensitivity disorders of the ocular surface. Allergy. 2012;67(11):1327-37.

14. Saboo US, Jain M, Reddy JC, Sangwan VS. Demographic and clinical profile of Vernal Keratoconjunctivitis at a tertiary eye care center in India. Indian J Ophthalmol. 2013;61(9):486-9.

15. De Smedt S, Nkurikiye J, Fonteyne Y, Hogewoning A, Esbroeck MV, De Bacquer D, et al. Am J Trop Med Hyg. 2011;85(4):711-7.

16. McCabe CF, McCabe SE. Comparative efficacy of bepotastine besilate $1.5 \%$ ophthalmic solution versus olopatadine hydrochloride $0.2 \%$ ophthalmic solution evaluated by patient preference. Clini Ophthalmol (Auckland, NZ). 2012;6:1731-8.

Cite this article as: Malahat AR, Kodudula S, Gali VL. A prospective comparative study to evaluate the efficacy and safety of olopatadine eye drops and bepotastine eye drops in subjects of vernal kerato conjunctivitis. Int J Basic Clin Pharmacol 2020;9:706-11. 